\title{
Analisis Perbandingan Performa Metode Klasifikasi pada Dataset Multiclass Citra Busur Panah
}

\author{
Performance Comparison Analysis of Classification Methods on the Multiclass Dataset \\ of Bows
}

\author{
Huzain Azis ${ }^{1}$, Fadhila Tangguh Admojo ${ }^{2}$, Erma Susanti ${ }^{3}$ \\ ${ }^{1}$ Teknik Informatika, Fakultas Ilmu Komputer, Universitas Muslim Indonesia \\ ${ }^{2}$ Teknik Informatika, STMIK Palcomtech \\ 1,2,3 Informatika, Fakultas Teknologi Industri, Institut Sains \& Teknologi, AKPRIND \\ E-mail: ${ }^{1}$ huzain.azis@ umi.ac.id, ${ }^{2}$ Fadhila.tangguh@gmail.com, ${ }^{3}$ erma@akprind.ac.id
}

\begin{abstract}
Abstrak
Pengujian performa berbagai metode pada sebuah dataset merupakan salah satu cara dalam penetapan metode klasifikasi yang tepat, masalah yang diangkat pada penelitian ini adalah bagaimana membandingkan performa beberapa metode klasifikasi dalam mengelola dataset yang memiliki lebih dari dua label (multiclass). Penelitian ini fokus membandingkan hasil performa tujuh metode klasifikasi yaitu K-Nearest Neighbor (knn), Naive Bayes Classifier (nbc), Support Vector machine (svm), Neural Netowork (nn), Random Forest Classifier (rfc), Ada Boost Classifier (abc) dan Quadratic Discriminant Analysis (qdc). Objek pada penelitian ini berupa dataset multiclass yaitu dataset citra busur panah, serta performa yang diukur yaitu seluruh nilai cross-validation dari akurasi, presisi, recall dan $f$-measure. Hasil pada penelitian ini menunjukkan bahwa seluruh metode tidak memperoleh performa yang cukup baik, dan menunjukkan bahwa beberapa metode yang memiliki akurasi yang tinggi tidak menjadi penentu menjadi metode yang baik dikarenakan setelah penerapan cross-validation dan visualisasi boxplot ditemukan beberapa nilai akurasi tinggi yang merupakan nilai tidak wajar atau outlier. Kesimpulan menunjukkan metode svm memiliki performa yang lebih baik dibandingkan dengan enam metode lainnya pada kasus dataset multiclass citra busur panah.
\end{abstract}

Kata kunci: analisis performa, klasifikasi, dataset multiclass, cross-validation, perbandingan metode

\begin{abstract}
Testing the performance of various methods on a dataset is one way in determining the appropriate classification method. The problem raised in this study is how to compare the performance of several classification methods in managing datasets that have more than two labels (multiclass). This study focuses on analyzing the results of performance seven classification methods namely K-Nearest Neighbor (knn), Naive Bayes Classifier (nbc), Support Vector Machine (svm), Neural Netowork (nn), Random Forest Classifier (rfc), Ada Boost Classifier (abc) and Quadratic Discriminant Analysis ( $q d c)$. The object is a multiclass dataset, which is the bow image dataset, and the performance measured in this study is all the crossvalidation values of accuracy, precision, recall and f-measure. The results of this study indicate that all methods do not get good enough performance, and show that some plans that have high accuracy are not decisive to be suitable methods because after the application of crossvalidation and boxplot visualization. Several high accuracy values are identified to be unnatural or outlier, the conclusion shows that the svm method has a better performance compared to the six other ways in the case of the bow multiclass dataset.
\end{abstract}

Keywords: performance analysis, classification, multiclass dataset, cross-validation, method comparison 


\section{PENDAHULUAN}

Terdapat banyak metode klasifikasi dalam supervised learning pada machine learning, diantaranya adalah K-Nearest Neighbor (knn), Naive Bayes Classifier (nbc), Support Vector Machine (svm), Neural Netowork (nn), Random Forest Classifier (rfc), Ada Boost Classifier (abc), serta Quadratic Discriminant Analysis (qda). Metode tersebut memiliki kelebihan serta kekurangannya masing-masing, salah satu faktor menjadi keunggulan metode klasifikasi tersebut dilihat dari bagaimana metode tersebut mengolah objek dataset. Dataset multiclass merupakan dataset unik yang memiliki lebih dari dua label. performa sebuah metode dapat diukur melalui pengujian nilai akurasi, presisi, recall dan $f$-measure, serta dengan menerapkan cross-validation pada pengujian performa maka kekokohan dari performa tersebut dapat terihat.

Saat ini terdapat banyak penelitian mengenai penerapan atau perbandingan metode klasifikasi serta penerapannya di berbagai jenis dataset[1]. Tabel 1 menunjukkan perbandingan ruang lingkup penelitian sebelumnya dengan penelitian ini. Penelitian ini mencoba mengukur serta membandingkan performa tujuh metode klasifikasi yaitu knn, nbc, svm, nn, rfc, abc dan qda pada dataset multiclass citra busur panah yang terdiri dari empat label dimana data yang digunakan untuk klasifikasi merupakan output dari deteksi tepi serta ekstraksi fitur citra.

Tabel 1 Gap Penelitian Terkait

\begin{tabular}{|c|c|c|c|c|c|c|c|c|}
\hline \multirow{2}{*}{ No } & \multirow{2}{*}{$\begin{array}{c}\text { Tahun } \\
\text { Penelitian }\end{array}$} & \multirow{2}{*}{ Metode } & \multirow{2}{*}{$\begin{array}{c}\text { Multiclass } \\
\text { Dataset }\end{array}$} & \multirow{2}{*}{$\begin{array}{c}\text { Cross- } \\
\text { validation }\end{array}$} & \multicolumn{4}{|c|}{ Performa } \\
\hline & & & & & akurasi & presisi & recall & F-measure \\
\hline 3 & [3] 2019 & knn & $\checkmark$ & - & $\checkmark$ & $\checkmark$ & $\checkmark$ & $\checkmark$ \\
\hline \multirow{3}{*}{4} & \multirow[t]{3}{*}{ [4] 2017} & knn & - & - & $\sqrt{ }$ & - & - & - \\
\hline & & $\mathrm{nb}$ & - & - & $\checkmark$ & - & - & - \\
\hline & & svm & - & - & $\checkmark$ & - & - & - \\
\hline \multirow[b]{2}{*}{5} & \multirow[t]{2}{*}{ [5] 2016} & $\mathrm{dt}$ & - & $\checkmark$ & $\checkmark$ & - & - & - \\
\hline & & knn & - & $\checkmark$ & $\checkmark$ & - & - & - \\
\hline \multirow{3}{*}{7} & \multirow{3}{*}{ [7] 2015} & $\mathrm{Nbc}$ & - & $\checkmark$ & $\checkmark$ & - & - & - \\
\hline & & $\mathrm{j} 48$ & - & $\checkmark$ & $\checkmark$ & - & - & - \\
\hline & & Svm & - & $\checkmark$ & $\checkmark$ & - & - & - \\
\hline
\end{tabular}

Tabel 1 menunjukkan bahwa keterkaitan serta gap penelitian ini dengan penelitian sebelumnya yaitu terdapat pada jumlah metode klasifikasi yang dibandingkan, jenis dataset yang digunakan (multiclass atau bukan), penerapan crossvalidation, dan jenis performa yang diukur (akurasi, presisi dan recall). Tahapan penelitian ini dan penelitian-penelitian sebelumnya jelas akan berbeda tergantung pada metode apa yang dibandingkan serta objek dataset yang digunakan.

Tahap yang dilakukan pada penelitian ini adalah deteksi tepi citra menggunakan canny, ekstraksi fitur menggunakan humoment, splitting data training dan data testing sebanyak 5 fold menggunakan cross-validation, menerapkan tujuh metode klasifikasi, serta menghitung performa masing-masing metode yang akan diuji. Perbedaan penelitian ini dengan penelitian sebelumnya yaitu dari jenis dataset yang digunakan, jumlah metode yang dibandingkan, serta penerapan cross-validation untuk uji kekokohan performa. 


\section{METODE PENELITIAN}

Dataset yang digunakan pada penelitian ini merupakan dataset dengan format citra, yang dikumpulkan dengan melakukan proses image crawling pada google image searcher, jumlah label (class) sebanyak empat yaitu gambar dengan label recurve bow, longbow, compound bow, dan crossbow.

Jumlah keseluruhan gambar dataset sebanyak 800 yang dapat diunduh Pada repositori dataset kaggle. Adapun tahap analisis yang dilakukan pada penelitian ini terdiri dari segmentasi, ekstraksi fitur, cross-validation, klasifikasi dan menghitung performa, Gambar 1 menunjukkan tahapan analisis pada penelitian ini.

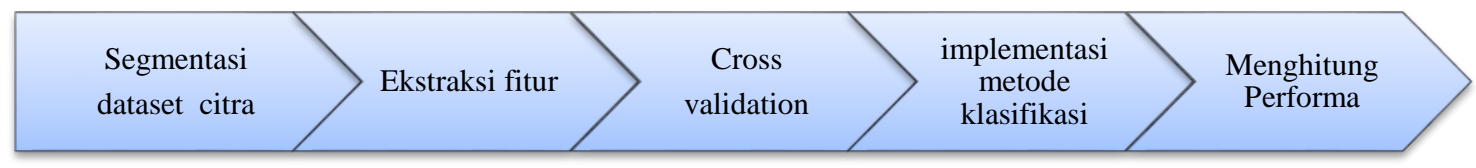

\subsection{Segmentasi dataset citra}

Gambar 1 Tahapan analisis

Tahap pertama adalah segmentasi citra, pada tahap ini terdapat 2 sub tahapan inti yaitu melakukan deteksi tepi menggunaka canny serta reduce noise menggunakan gaussianblur [6][7], persamaan 1 menunjukkan persamaan deteksi tepi canny dan Tabel 2 menunjukkan implementasi deteksi tepi canny pada dataset citra.

$$
\begin{gathered}
E G(G)=\sqrt{G_{x}^{2}+G_{y}^{2}} \\
\operatorname{Angel}(\theta)=\tan ^{-1}\left(\frac{G_{y}}{G_{x}}\right)
\end{gathered}
$$

Tabel 2. Implementasi Segmentasi

\begin{tabular}{|c|c|c|}
\hline Citra Asli & Canny & Canny + gauusian blur \\
\hline & \\
\hline
\end{tabular}

\subsection{Ekstraksi fitur}

Tahap kedua adalah ekstraksi fitur, pada tahap ini metode yang digunakan adalah ekstraksi fitur humoment, dimana akan dilakukan proses pengambilan tujuh fitur pada setiap gambar.

Persamaan 2 menunjukkan formula yang digunakan untuk mengambil fitur pada gambar. fitur yang diekstrak pada setiap gambar sebanyak 7 fitur [8][9], sedangkan Tabel 3 menunjukkan lima contoh hasil ekstraksi fitur pada sebuah gambar yang telah melalui 
segmenteasi sebelumnya, alasan penggunaan humoment dengan pertimbangan bahwa nilai humoment invariant baik terhadap skala ukuran objek dan rotasi, menimbang bahwa dataset yg diolah merupakan dataset yang memiliki perbedaan yang berbeda ukuran serta rotasinya.

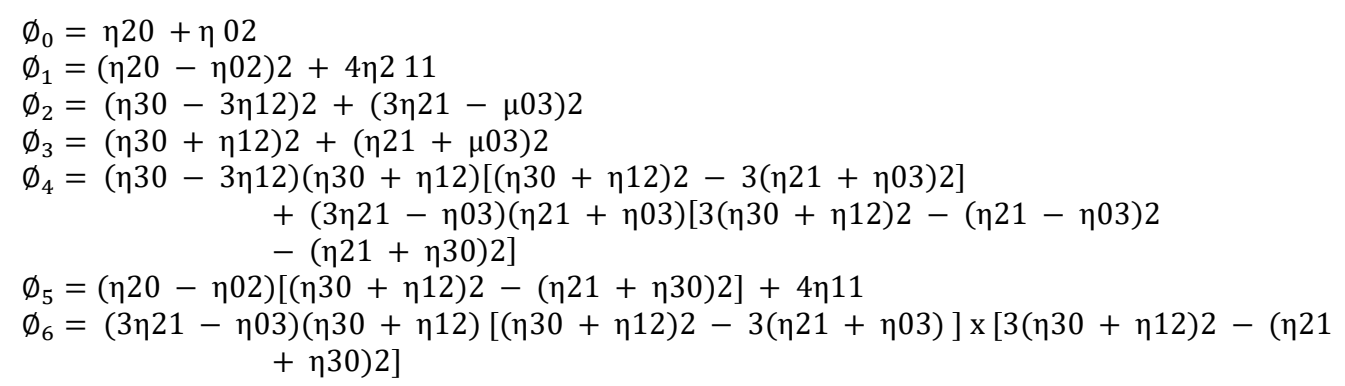

Tabel 3. Implementasi Ekstraksi fitur Humoment

\begin{tabular}{|c|c|c|c|c|c|c|}
\hline$\varnothing \mathbf{0}$ & $\varnothing \mathbf{1}$ & $\varnothing \mathbf{2}$ & $\varnothing \mathbf{3}$ & $\varnothing \mathbf{4}$ & $\varnothing \mathbf{5}$ & $\emptyset \mathbf{6}$ \\
\hline 0.01275 & $1.31 \mathrm{E}-04$ & $2.54 \mathrm{E}-07$ & $4.76 \mathrm{E}-08$ & $2.58 \mathrm{E}-15$ & $4.02 \mathrm{E}-12$ & $-4.55 \mathrm{E}-15$ \\
\hline 0.009296 & $5.01 \mathrm{E}-07$ & $1.18 \mathrm{E}-08$ & $2.86 \mathrm{E}-09$ & $-1.60 \mathrm{E}-17$ & $-1.93 \mathrm{E}-12$ & $-4.37 \mathrm{E}-18$ \\
\hline 0.00663 & $1.20 \mathrm{E}-07$ & $1.24 \mathrm{E}-09$ & $3.91 \mathrm{E}-10$ & $-2.20 \mathrm{E}-19$ & $1.21 \mathrm{E}-13$ & $-1.60 \mathrm{E}-19$ \\
\hline 0.012702 & $1.42 \mathrm{E}-04$ & $1.32 \mathrm{E}-07$ & $2.00 \mathrm{E}-08$ & $8.03 \mathrm{E}-17$ & $-7.07 \mathrm{E}-11$ & $1.03 \mathrm{E}-15$ \\
\hline 0.009711 & $7.99 \mathrm{E}-05$ & $6.27 \mathrm{E}-08$ & $3.48 \mathrm{E}-08$ & $1.60 \mathrm{E}-15$ & $2.54 \mathrm{E}-10$ & $2.81 \mathrm{E}-16$ \\
\hline
\end{tabular}

\subsection{Cross-validation}

Tahap ketiga adalah tahap proses cross-validation, sesuai dengan defenisinya bahwa cross-validation merupakan metode statistik yang ampuh diterapkan untuk mengevaluasi kinerja model maupun algoritma dimana data dipilah menjadi dua bagian yaitu data proses training dan data testing[10], [11]. Model atau algoritma dilatih oleh subset pembelajaran dan divalidasi oleh subset validasi agar pengambilan nilai performa dapat disimpulkan dengan baik maka setiap data pada keseluruhan dataset dirancang agar bergilir untuk berperan sebagai data training dan data testing, penerapan cross-validation pada tahap ini dibagi menjadi 5 bagian atau juga disebut sebagai k-5 fold validation. Gambar 2 menunjukkan ilustrasi cross-validation pada penelitian ini.

\begin{tabular}{|c|c|c|c|c|c|}
\hline & Fold 1 & Fold 2 & Fold 3 & Fold 4 & Fold 5 \\
\hline Split 1 & Fold 1 & Fold 2 & Fold 3 & Fold 4 & Fold 5 \\
\hline Split 2 & Fold 1 & Fold 2 & Fold 3 & Fold 4 & Fold 5 \\
\hline Split 3 & Fold 1 & Fold 2 & Fold 3 & Fold 4 & Fold 5 \\
\hline Split 4 & Fold 1 & Fold 2 & Fold 3 & Fold 4 & Fold 5 \\
\hline Split 5 & Fold 1 & Fold 2 & Fold 3 & Fold 4 & Fold 5 \\
\hline
\end{tabular}

Gambar 2 Implementasi cross-validation

\subsection{Implementasi metode klasifikasi}

Tahap selanjutnya adalah melakukan testing pada tujuh metode klasifikasi yaitu knn, nbc, svm, nn, rfc, abc dan qda. Metode pertama yang diuji adalah metode knn dimana metode tersebut memutuskan hasil klasifikas berdasarkan dominan tetangga yang terdekat. Persamaan 3 menunjukkan rumus penerapan metode knn yang mana algoritma jarak yang digunakan pada metode knn adalah eucidien[3][2]. 


$$
e u c=\sqrt{\sum_{r=1}^{n}\left(a_{r}\left(x_{i}\right)-a_{r}\left(x_{j}\right)\right)^{2}}
$$

Metode klasifikasi kedua adalah Support Vector Machine (svm), pada dasarnya terdapat tiga implementasi berbeda dari Regresi Vektor: SVR, NuSVR dan LinearSVR [10], [11]. LinearSVR menyediakan implementasi yang lebih cepat daripada SVR tetapi linearSVR hanya fokus pada kernel linier, sementara NuSVR mengimplementasikan formulasi yang sedikit berbeda dari SVR dan LinearSVR. Penerapan metode svm pada penelitian ini menggunakan LinearSVR yang ditunjukkan pada persamaan 4.

$$
\left.\operatorname{Min}_{w, b} \frac{1}{2} w^{t} w+C \sum_{i=1} \max \left(0, \mid y_{i}-w^{t} \emptyset\left(x_{i}\right)+b\right) \mid-\varepsilon\right)
$$

Metode yang ketiga yang adalah Multi-Layer Perceptron (MLP) dalam hal ini adalah salah satu pemodelan dalam Neural Network [12], formulanya memberikan serangkaian training dimana $\left(x_{1}, y_{1}\right),\left(x_{2}, y_{2}\right), \ldots,\left(x_{n}, y_{n}\right)$ dimana $x_{1} \in R^{n}$ dan $y_{1} \in\{0,1\}$, satu hidden layer satu hidden neuron MLP mempelajari fungsinya $f(x)=W_{2 g}\left(W_{1}^{T} x+b_{1}\right)+b_{2} \operatorname{dimana} W_{1} \in R^{m}$ dan $W_{2}, b_{1}, b_{2} \in R$ adalah parameter model. Namun jika terdapat lebih dari 2 class maka $f(x)$ itu sendiri akan menjadi vektor ukuran (n_classes,)., dan akan melewati fungsi softmax [13], Formula softmax ditunjukkan pada persamaan 5.

$$
\operatorname{softmax}(z)_{1}=\frac{\exp \left(z_{i}\right)}{\sum_{l=1}^{k} \exp \left(z_{i}\right)}
$$

Metode keempat adalah Nä̈ve Bayes Classifier (nbc), metode yang sangat popular yang melakukan proses klasifikasinya dengan pendekatan probabilitas. dikarenakan data yang diolah merupakan data numeric maka fungsi yang diterapkan menggunakan gaussian naïve bayes [14]-[16], persamaan 6 menunjukkan fungsi yang digunakan pada gaussian nä̈ve bayes.

$$
P\left(x_{i} \mid y\right)=\frac{1}{\sqrt{2 \pi \sigma_{y}^{2}}} \exp \left(-\frac{\left(x_{i}-\mu_{y}\right)^{2}}{2 \sigma_{y}^{2}}\right)
$$

Tiga metode lainnya yaitu rfc, abc dan qda, dimana Random forests adalah kombinasi 3 pohon keputusan yang mana setiap pohon bertanggung jawab pada setipa nilai dari random vector yang diberikan begitupun persebarannya akan diberikan kepada pohon keputusan lainnya[10][17]. Sama halnya dengan rfc, abc juga merupakan ensamble method yang juga dapat digunakan untuk melakukan proses klasifikasi dataset multiclass[18]. Sedangkan qda, merupakan pengklasifikasi dengan batas keputusan kuadratik, dihasilkan dengan menyesuaikan kepadatan class dengan data dan menggunakan aturan Bayes[19][20].

\subsection{Menghitung performa}

Tahap terakhir setelah penerapan metode klasifikasi adalah menghitung performa, adapun persamaan performa menggunakan confusion matrix yang mana untuk membantu menghitung nilai akurasi, presisi, recall dan f-measure[21][22][23]. Tabel 4. menunjukkan model confusion matrix yang diterapkan untuk kasus 4 label dimana $R e$ untuk label recursive bow, Lo untuk Label Long bow, Co untuk label Compound Bow dan Cr untuk Cross bow. 
Tabel 4. Confusion Matrix Multiclass

\begin{tabular}{|c|c|c|c|c|c|}
\cline { 2 - 6 } \multicolumn{1}{c|}{} & \multicolumn{5}{|c|}{ classifier } \\
\cline { 2 - 6 } Actual & & $R e$ & $L o$ & $C o$ & $C r$ \\
\cline { 2 - 6 } & Re & ReRe & ReLo & ReCo & $\mathrm{ReCr}$ \\
\cline { 2 - 6 } & $L o$ & LoRe & LoLo & LoCo & $\mathrm{LoCr}$ \\
\cline { 2 - 6 } & $C o$ & CoRe & CoLo & CoCo & CoCr \\
\cline { 2 - 6 } & $C r$ & CrRe & CrLo & CrCo & CrCr \\
\hline
\end{tabular}

Persamaan yang digunakan untuk menghitung akurasi ditunjukkan pada persamaan 7 , penerapan perhitungan akurasi yang digunakan pada penelitian ini adalah balanced-accuracy (ba) dimana berfungsi untuk menangani multiclass klasifikasi dengan data yang tidak seimbang[24], [25].

$$
\begin{aligned}
& \text { accuracy }=\frac{T P+T N}{T P+T N+F P+F N} \\
& \text { b. } a=1 / 2\left(\frac{T P}{T P+F N}+\frac{T N}{T N+F P}\right)
\end{aligned}
$$

Proses klasifikasi multiclass, perhitungan performa presisi, recall, dan f-measure dapat diterapkan pada setiap label secara independen [18][19]. presisi menggunakan persamaan 8, persamaan 9 menunjukan perhitungan performa recall dan persamaan 10 untuk $f$ measure[28][29].

$$
\begin{gathered}
\text { precision }=\frac{T P}{T P+F P} \\
\text { recall }=\frac{T P}{T P+F N} \\
f-\text { measure }=\frac{\text { precision } * \text { recall }}{\text { precison }+ \text { recall }}
\end{gathered}
$$

\section{HASIL DAN PEMBAHASAN}

Setelah melalui keseluruhan Tahapan, maka diperolehlah nilai performa untuk semua metode, Tabel 4. Memperlihatkan performa pada setiap metode yang dianalisis pada penelitian ini, performa yang diperlihatkan terdiri dari akurasi, presisi, recall, dan f-measure. dimana nilai

\begin{tabular}{|c|c|c|c|c|c|}
\hline No & Metode & Akurasi & Presisi & Recall & F-measure \\
\hline 1 & K-Nearest Neighbor (k-nn), & $73 \%$ & $68 \%$ & $73 \%$ & $67 \%$ \\
\hline 2 & Naive Bayes Classifier (nbc), & $71 \%$ & $69 \%$ & $71 \%$ & $68 \%$ \\
\hline 3 & Support Vector Machine (svm), & $73 \%$ & $61 \%$ & $73 \%$ & $66 \%$ \\
\hline 5 & Random Forest Classifier (rfc), & $73 \%$ & $60 \%$ & $73 \%$ & $65 \%$ \\
\hline 6 & Ada Boost Classifier (abc), & $74 \%$ & $61 \%$ & $74 \%$ & $67 \%$ \\
\hline
\end{tabular}
tersebut diambil dari nilai tertinggi dari pada setiap simulasi data 5-fold crossvalidation yang telah diatur sebelumnya. Nilai performa pada setiap crossvalidation diilustrasikan pada Gambar 4, dimana ilustrasi visualisasi yang diperlihatkan dalam bentuk linegraph

Tabel 4. Hasil Pengujian

Gambar 3 menunjukkan visualisasi setiap metode dalam format boxplot. Terlihat bahwa setiap metode ilustrasi menunjukkan terdapat nilai outlier, baik terdapat di akurasi, presisi, recall maupun f-measure. Performa sebuah metode tidak cukup jika diukur dari nilai akurasi 
saja, namun juga perlu dilihat nilai presisi, recall maupun f-measure. Selain itu dengan melakukan simulasi crossvalidation juga dapat membuat nilai performa yang tidak wajar atau juga disebut anomali(outlier).

Berdasarkan apa yang ditunjukkan pada Tabel 4 dan jika disandingkan dengan Gambar 3, bisa dilihat bahwa Meskipun Ada Boost Classifier (abc) memiliki nilai akurasi tertinggi sebesar 74\%, namun visualisasi dalam bentuk boxplot terlihat bahwa nilai akurasi yang tertinggi tersebut merupakan nilai yang tidak wajar atau disebut outlier dari nilai hasil crossvaldation lainnya. Begitupula terlihat pada metode knn dan rfc dengan akurasi $73 \%$ juga merupakan nilai outlier diantara nilai crossvalidation lainnya

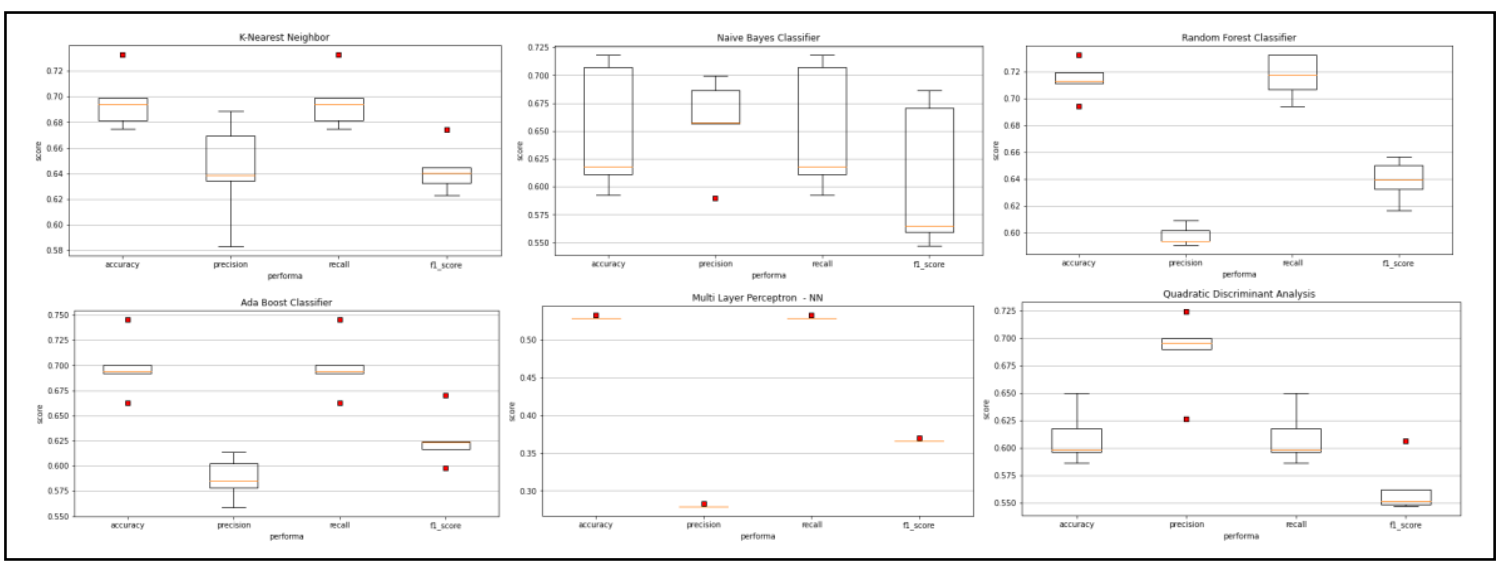

Gambar 3. Ilustrasi visualisasi performa dalam boxplot

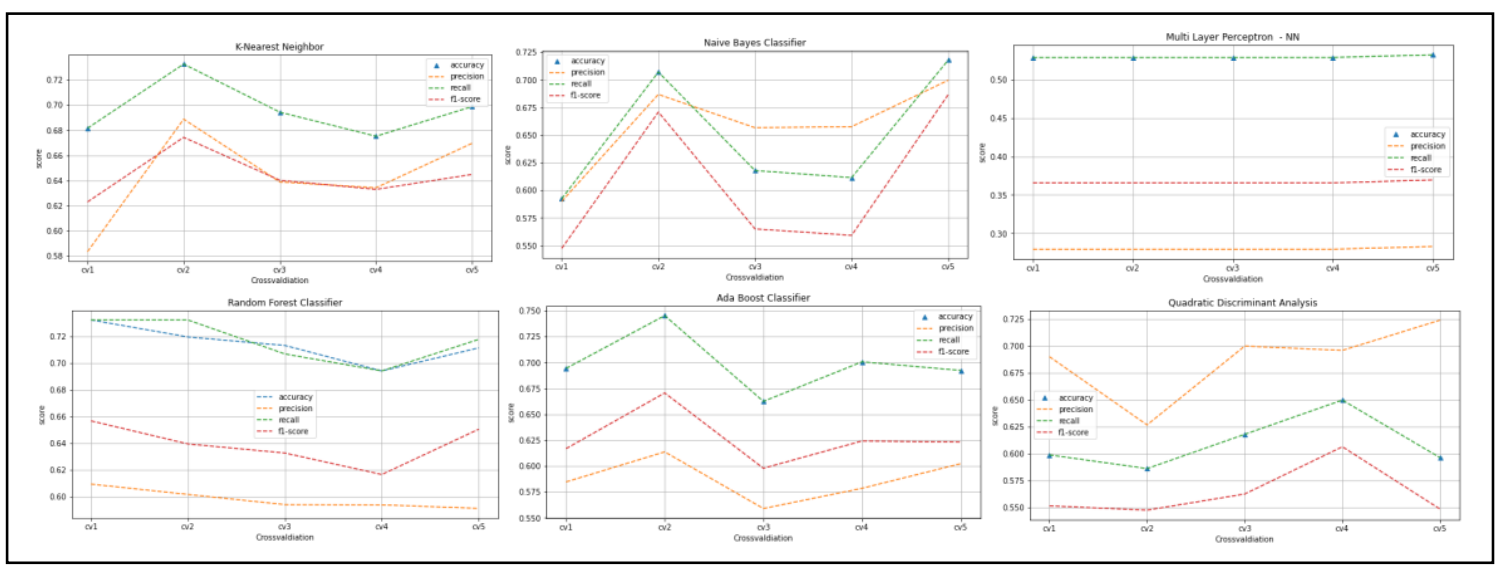

Gambar 4. Boxlot dan linegraph metode svm

Gambar 4 menunjukkan visualisasi performa metode pada 5-fold crossvalidation. Sedangkan Gambar 5 menunjukkan boxplot serta linegraph metode svm, Nilai performa yang menjadi outlier tidak dapat digunakan sebagai nilai performa yang baik, sehingga penetapan nilai terbaik pada percobaan ini jatuh pada metode svm yang memilik nilai akurasi $73 \%$, jika dibandingkan dengan nilai performa yang lain terlihat bahwa nilai performa pada metode svm tidak memiliki satupun nilai outlier, baik pada performa akurasi, presisi, recall dan F-Measure. Sehingga alasan tersebut membuat metode svm menjadi metode yang lebih baik dibanding metode lainnya pada studi kasus klasifikasi dataset multiclass citra busur panah 


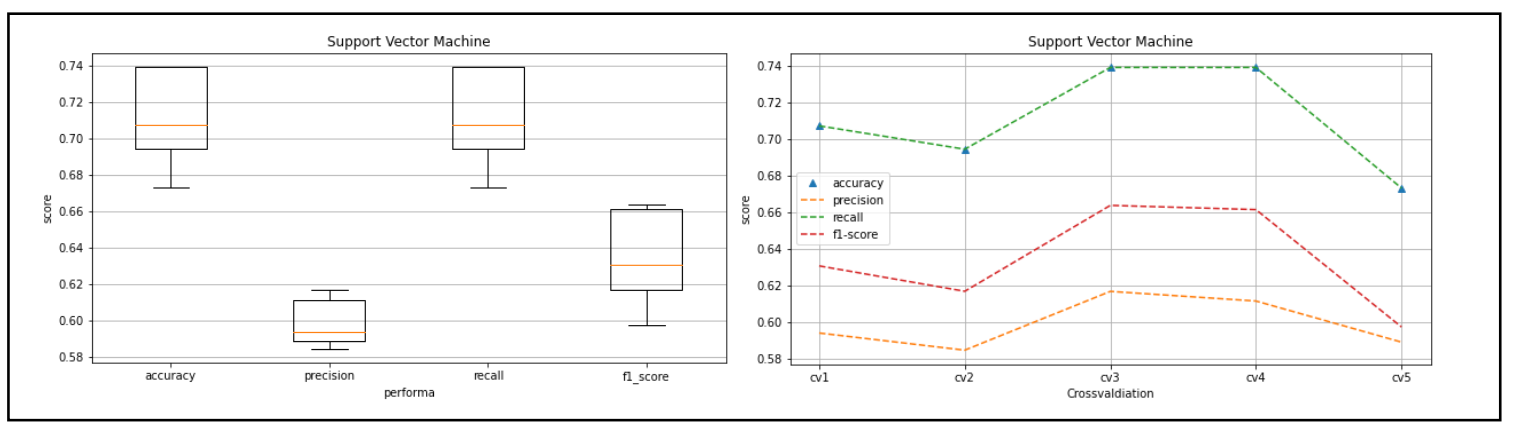

Gambar 5 Boxlot dan linegraph metode svm

\section{KESIMPULAN DAN SARAN}

Setelah melalui berbagai simulasi dapat disimpulkan bahwa meskipun secara keseluruhan semua metode tidak mendapatkan nilai performa yang sangat baik, namun metode svm memiliki nilai performa yang lebih baik dibandingkan metode klasifikasi lainnya dalam studi kasus klasifikasi dataset multiclass busur panah, Serta dapat dibuktikan bahwa jika hanya dengan melihat nilai akurasi maka tidak cukup untuk menunjukkan bagus maupun tidaknya performa metode tersebut. Banyak pertimbangan yang dapat dilakukan dalam menentukan metode yang tepat yaitu dengan menghitung keseimbangan hasil pengujian seperti presisi, recall, f-measure serta dengan melakukan uji coba berbagai simulasi pembagian data ujianya menggunakan crossvalidation.

\section{DAFTAR PUSTAKA}

[1] N. Fadhillah, H. Azis, and D. Lantara, "Validasi Pencarian Kata Kunci Menggunakan Algoritma Levenshtein Distance Berdasarkan Metode Approximate String Matching," Pros. Semin. Nas. Ilmu Komput. dan Teknol. Inf., vol. 3, no. 2, pp. 3-7, 2018.

[2] Hasran, "Klasifikasi Penyakit Jantung Menggunakan Metode K-Nearest Neighbor," Indones. J. Data Sci., vol. 1, no. 1, pp. 1-4, 2020.

[3] M. M. Baharuddin, T. Hasanuddin, and H. Azis, "Analisis Performa Metode K-Nearest Neighbor untuk Identifikasi Jenis Kaca,” Ilk. J. Ilm., vol. 11, no. 28, pp. 269-274, 2019.

[4] A. Ilham, "Komparasi Algoritma Klasifikasi Dengan Pendekatan Level Data Untuk Menangani Data Kelas Tidak Seimbang," J. Ilm. Ilmu Komput., vol. 3, no. 1, pp. 9-14, 2017.

[5] M. Yusa, E. Utami, and E. T. Luthfi, "Analisis Komparatif Evaluasi Performa Algoritma Klasifikasi pada Readmisi Pasien Diabetes," J. Buana Inform., vol. 7, no. 4, pp. 293302, 2016, doi: 10.24002/jbi.v7i4.770.

[6] Rizky Ade Putranto, Triastiti Wuryandari, and Sudarno, "Perbandingan Analisis Klasifikasi Antara Decision Tree Dan Support Vector Machine Multiclass Untuk Penentuan Jurusan Pada Siswa Sma,” J. Gaussian, vol. 4, no. 4, pp. 1007-1016, 2015.

[7] Y. Lukito and A. R. Chrismanto, "Perbandingan Metode-Metode Klasifikasi untuk Indoor Positioning System," J. Tek. Inform. dan Sist. Inf., vol. 1, no. 2, pp. 123-131, 2015, doi: 10.28932/jutisi.v1i2.373.

[8] S. Niu, J. Yang, S. Wang, and G. Chen, "Improvement and parallel implementation of canny edge detection algorithm based on GPU," Proc. Int. Conf. ASIC, no. 6, pp. 641644, 2011, doi: 10.1109/ASICON.2011.6157287.

[9] W. Ye, Y. Xia, and Q. Wang, "An Improved Canny Algorithm for Edge Detection," J. Comput. Inf. Syst., vol. 75, pp. 1516-1523, 2011, doi: 10.1109/WCSE.2009.718.

[10] T. F. Wu, C. J. Lin, and R. C. Weng, "Probability estimates for multi-class classification 
by pairwise coupling," J. Mach. Learn. Res., vol. 5, pp. 975-1005, 2004.

[11] K. Crammer, "On the algorithmic implementation of multiclass kernel-based vector machines," J. Mach. Learn. Res. - JMLR, vol. 2, no. 2, pp. 265-292, 2002.

[12] M. J. Hartmann and G. Carleo, "Neural-Network Approach to Dissipative Quantum Many-Body Dynamics," Phys. Rev. Lett., vol. 122, no. 25, p. 250502, Jun. 2019, doi: 10.1103/PhysRevLett.122.250502.

[13] B. Gao and L. Pavel, "On the Properties of the Softmax Function with Application in Game Theory and Reinforcement Learning," 2017.

[14] H. Zhang, "The optimality of Naive Bayes," Proc. Seventeenth Int. Florida Artif. Intell. Res. Soc. Conf. FLAIRS 2004, vol. 2, pp. 562-567, 2004.

[15] V. Metsis, I. Androutsopoulos, and G. Paliouras, "Spam filtering with Naive Bayes Which Naive Bayes?," 3rd Conf. Email Anti-Spam - Proceedings, CEAS 2006, 2006.

[16] M. Christopher, P. Raghavan, and H. Schutze, An Introduction to Information Retrieval. Cambridge University Press, 2009.

[17] Y. L. Pavlov, "Random forests," Random For., pp. 1-122, 2019, doi: 10.1201/9780367816377-11.

[18] T. Hastie, S. Rosset, J. Zhu, and H. Zou, "Multi-class AdaBoost," Stat. Interface, vol. 2, no. 3, pp. 349-360, 2009, doi: 10.4310/sii.2009.v2.n3.a8.

[19] R. Puri and K. Khamrui, "Application of Quantitative Descriptive Analysis (QDA), Principal Component Analysis (PCA) and Response Surface Methodology (RSM) in standardization of cham-cham making.," 2015.

[20] A. Tharwat, "Linear vs. quadratic discriminant analysis classifier: a tutorial," Int. $J$. Appl. Pattern Recognit., vol. 3, no. 2, p. 145, 2016, doi: 10.1504/ijapr.2016.079050.

[21] A. Tharwat, "Classification assessment methods," Appl. Comput. Informatics, 2018, doi: 10.1016/j.aci.2018.08.003.

[22] P. A. Flach and M. Kull, "Precision-Recall-Gain curves: PR analysis done right," $A d v$. Neural Inf. Process. Syst., vol. 2015-Janua, pp. 838-846, 2015.

[23] L. Nurhayati and H. Azis, "Perancangan Sistem Pendukung Keputusan Untuk Proses Kenaikan Jabatan Struktural Pada Biro Kepegawaian," Semin. Nas. Teknol. Inf. dan Multimed., pp. 6-7, 2016.

[24] J. D. Kelleher, B. Mac Namee, and A. D. Arcy, Fundamentals of Machine Learning For Predictive Data Analytics Algorithms, Worked Examples, and Case Studies. London: The MIT Press, 2015.

[25] K. H. Brodersen, C. S. Ong, K. E. Stephan, and J. M. Buhmann, "The balanced accuracy and its posterior distribution," Proc. - Int. Conf. Pattern Recognit., pp. 3121-3124, 2010, doi: 10.1109/ICPR.2010.764.

[26] A. A. Karim, H. Azis, and Y. Salim, "Kinerja Metode C4.5 dalam Penyaluran Bantuan Dana Bencana 1," Pros. Semin. Nas. Ilmu Komput. dan Teknol. Inf., vol. 3, no. 2, pp. 8487, 2018.

[27] A. Fitria and H. Azis, "Analisis Kinerja Sistem Klasifikasi Skripsi menggunakan Metode Naïve Bayes Classifier," Pros. Semin. Nas. Ilmu Komput. dan Teknol. Inf., vol. 3, no. 2, pp. 102-106, 2018.

[28] S. Paembonan et al., "Combination of K-Means and Profile Matching for Drag Substitution," in 2018 2nd East Indonesia Conference on Computer and Information Technology (EIConCIT), Nov. 2018, pp. 180-183, doi: 10.1109/EIConCIT.2018.8878539.

[29] D. Chicco and G. Jurman, "The advantages of the Matthews correlation coefficient (MCC) over F1 score and accuracy in binary classification evaluation," BMC Genomics, vol. 21, no. 1, pp. 1-13, 2020, doi: 10.1186/s12864-019-6413-7. 